Short Communication

\title{
A simple protocol of DNA sequencing with $10 \%$ formamide for dissolving G/C compression
}

\author{
Kee-Ryeon Kang ${ }^{1}$ and Yeon Woong Kim ${ }^{1,2}$ \\ 1 Department of Biochemistry, College of Medicine, \\ Gyeongsang National University, Chinju 660-280, Korea \\ 2 Corresponding author
}

Accepted 13 November 1997

\begin{abstract}
Formamide has been widely used in urea/polyacrylamide gel to solve the compression problems that are occasionally found during the DNA sequencing of $\mathrm{G} / \mathrm{C}$ rich regions. In this study, however, $10 \%$ formamide was added in annealing solution in stead of adding to the gel. The compressions were unfolded efficiently with a more rapid annealing reaction on ice in the presence of $10 \%$ formamide.
\end{abstract}

Key words: formamide, DNA sequencing, T7 polymerase

\section{Introduction}

DNA sequencing has become a major tool for the analysis of genes. Reliable DNA sequencing systems that allow the determination of a fragment of DNA up to about 400 nucleotides are available (Sanger and Coulson, 1978). One of the problems encountered in sequencing is band compressions in the G/C-rich region. Sometimes formamide of at least $10 \%$ was used to improve its denaturing capability in urea/polyacrylamide sequencing gels (Rochelear et al., 1992). Formamide is known to lower the melting temperature of nucleic acid duplexes by weakening hydrogen bonds. Therefore it is widely applied to Southern and Northern blottings (Beyer, 1991), nuclease protection assays (Mironov et al., 1995), S1 mapping (Murray, 1986) and in situ hybridization (Hubbell, et al., 1976). To read the compressed sequences, two overlapping DNA strands are sequenced in both directions with 5'- and 3'-primers. However, it requires a lot of additional works like subcloning and primer preparation. Alternatively, substituting dGTP by dITP (Mills and Krammer, 1979) or 7-deazadGTP (Mizusawa et al., 1986) in the dideoxy sequencing reaction considerably reduced band compression by decreasing stacking energy of the folded structure. In this paper we described a simpler method to solve G/Ccompressions by involving $10 \%(\mathrm{v} / \mathrm{v})$ formamide in annealing reaction.

\section{Materials and Methods}

Two $\mathrm{ml}$ of XL-1 Blue E. coli harboring plasmid had been cultured overnight. The plasmid DNA was miniprepared according to conventional protocol and redissolved in 20 $\mu \mathrm{l}$ of deionized water. $5 \mu$ l was used for DNA sequencing.

\section{Denaturation of the double-stranded DNA}

Up to $10 \mathrm{ml}$ of miniprep DNA can be added to a $1.5-\mathrm{ml}$ microcentrifuge tube containing the mixture of $4 \mathrm{ml}$ of 2 $\mathrm{M} \mathrm{NaOH}, 4 \mu \mathrm{l}$ of 2 mM EDTA, pH 8.0 and $22 \mu \mathrm{l}$ of $\mathrm{H}_{2} \mathrm{O}$, which was prepared prior to use. The tube was vortexed gently and incubated at $37^{\circ} \mathrm{C}$ for $20 \mathrm{~min}$. Four $\mu \mathrm{l}$ of $2 \mathrm{M}$ ammonium acetate, $\mathrm{pH} 4.5$ was added and mixed gently. After $110 \mu \mathrm{l}$ of ethanol was added, denatured DNA was precipitated at $-20^{\circ} \mathrm{C}$ for $30 \mathrm{~min}$ or for at $-70^{\circ} \mathrm{C}$ for $15 \mathrm{~min}$. The salt-precipitated DNA was centrifuged at 3,000 rpm for $10 \mathrm{~min}$ in a microcentrifuge. The supernatant was removed carefully. The pellet was rinsed gently with icecold $70 \%$ ethanol and air-dried briefly.

\section{Annealing of primer to template}

The pellet was dissolved in a total volume of $14 \mu \mathrm{l}$ of the annealing mixture containing $10 \%(\mathrm{v} / \mathrm{v})$ formamide. Annealing mixture was composed of $2 \mu \mathrm{l}$ of annealing buffer $\left(280 \mathrm{mM}\right.$ Tris- $\mathrm{HCl}, \mathrm{pH} 7.5,100 \mathrm{mM} \mathrm{MgCl}_{2}$, and $350 \mathrm{mM} \mathrm{NaCl}$ ), $2 \mu \mathrm{l}$ of 1 pmol of primers, $8.6 \mu \mathrm{l}$ of $\mathrm{H}_{2} \mathrm{O}$, and $1.4 \mu \mathrm{l}$ of formamide. The solution stuck to wall of the centrifuge tube was collected by centrifugation briefly and heated at $95^{\circ} \mathrm{C}$ for 2 min (carefully so that its cap is not opened during boiling). The hot tube was transferred immediately to ice and cooled for $10 \mathrm{~min}$. The evaporated solution was centrifuged to the bottom of tube. While cooling is in progress, $2.5 \mu \mathrm{l}$ of each termination mix (G, A, T, C) was dispensed to a microsample plate. It was kept covered on ice until used.

\section{Labeling}

Labeling mixture was prepared by mixing the following components: $1.6 \mu$ of deionized water, $0.4 \mathrm{ml}$ of labeling $\operatorname{mix}(7.5 \mu \mathrm{M}$ dGTP, $7.5 \mu \mathrm{M}$ dCTP, and $7.5 \mu \mathrm{M}$ dTTP), 1 $\mu \mathrm{l}$ of $0.1 \mathrm{M} \mathrm{DTT}, 1.6 \mu \mathrm{l}$ of enzyme dilution solution which was supplied along with $\mathrm{T} 7$ polymerase $(20 \mathrm{mM}$ Tris- $\mathrm{HCl}$, $\mathrm{pH} 7.5,5 \mathrm{mM}$ DTT, $100 \mu \mathrm{g} \mathrm{BSA} / \mathrm{ml}$ and $5 \%$ glycerol), 1 


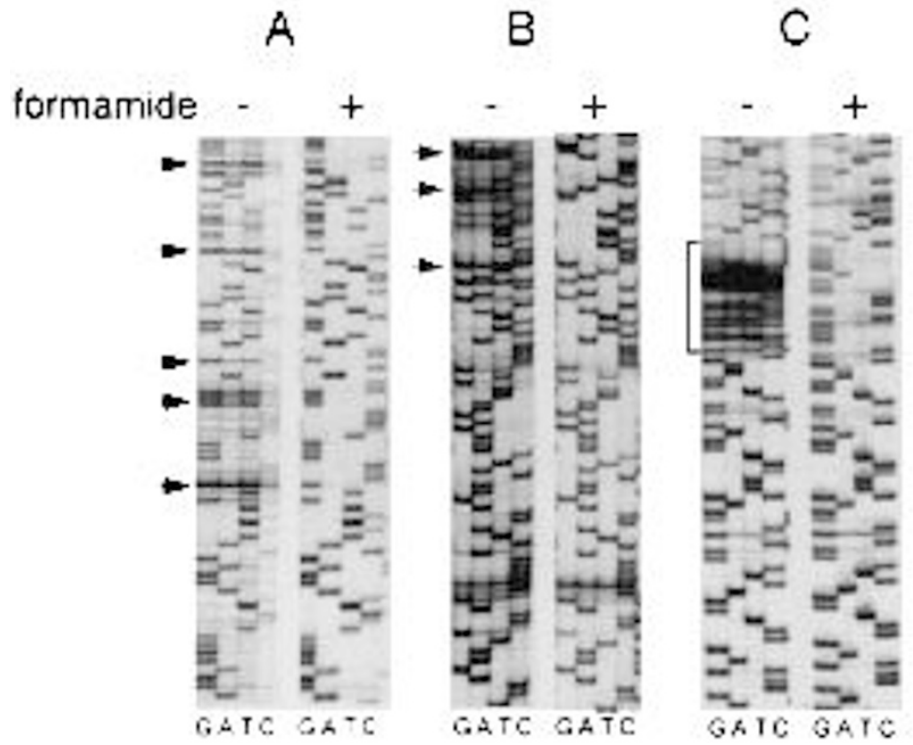

Figure 1. Nucleotide sequencing using the dideoxy-chain termination protocol. Inserts in vector Bluescript were sequenced with universal primers using $\mathrm{T} 7$ polymerase in the presence $(+)$ or absence $(-)$ of $10 \%$ (v/v) formamide in annealing solution. Several compressions are obvious in the sequencing ladder in the absence of formamide (left panels in $A, B$, and $C$ ). Compressions are indicated by arrows in panels $A$ and $B$ and $a$ bracket in $\mathrm{C}$. Electrophoresis was done on $5 \%$ urea/acrylamide sequencing gel at $60 \mathrm{~W}$ constant power. The gel was dried on a $3 \mathrm{MM}$ filter paper and exposed to a Hyperfilm (Amersham) overnight without intensifying screen. Parts of sequence of protein tyrosine phosphatase BDP1 above 230 bases and 120 bases from primer were shown in panels $A$ and $B$, respectively. Band compression in high GC region in BDP1, which is bracketed in panel $\mathrm{C}$, was also resolved. The electrophoresis was done until xylene cyanol FF reached the bottom in panel $\mathrm{A}$ and $\mathrm{C}$ and two thirds of the gel in panel $B$. $\mu \mathrm{l}$ of $\left[\alpha^{35} \mathrm{~S}\right] \mathrm{dATP}(1,000 \mathrm{Ci} / \mathrm{mmol}$, Amersham, Buckinghamshire, UK), and $0.4 \mu \mathrm{l}$ of T7 polymerase (8-12 U/ $\mu \mathrm{l}$, Pharmacia, Uppsala, Sweden). Labeling mixture was added and mixed with annealed solution by gentle pipetting without forming air bubbles. Labeling was performed for $4 \mathrm{~min}$ at room temperature.

\section{Termination}

Each aliquot of $4.5 \mu \mathrm{l}$ radio-labeled solution was mixed with each $G, A, T$, and $C$ termination mixes on ice by gentle pipetting. Termination was done for $5 \mathrm{~min}$ at $42^{\circ} \mathrm{C}$. After termination, $5 \mu$ of stop solution was added to each well and mixed. Stop solution was made by mixing $95 \%$ formamide, $20 \mathrm{mM}$ EDTA, pH 8.0, 0.03\% BPB, and 0.03\% xylene cyanol FF. Before loading a sample on sequencing gel, it was heated at $95^{\circ} \mathrm{C}$ for 2 min and cooled on ice quickly. 2-3 $\mathrm{ml}$ of each sample was applied to a well of sequencing gel. The remaining solution could be stored at $-20^{\circ} \mathrm{C}$ for 1 month. If further aliquots are to be loaded, samples can be done without heating.

\section{Results and Discussion}

To eliminate band compression $10 \%(\mathrm{v} / \mathrm{v})$ formamide was added to the annealing buffer. Annealing between sequencing primer and DNA template was carried out on ice for $5 \mathrm{~min}$ after 2-min denaturation of template DNA at $95^{\circ} \mathrm{C}$. $10 \%$ formamide in annealing step was diluted to $7 \%$ in labeling mixture and $4.8 \%$ in termination mixture. Application of this protocol to DNA sequencing of protein tyrosine phosphatase BDP1 (Kim et al., 1996) gave better results than without formamide as shown in Figure 1. In addition, time could be saved because of rapid annealing as well. Usually cooling was done slowly for $30 \mathrm{~min}$ or longer for annealing after incubation at $65^{\circ} \mathrm{C}$. This method could be applied to the known protocol such as those including single-stranded DNA with slight modification in annealing step. However, this could not be used when DTT is used in annealing buffer, because DTT is unstable on heat denaturation at $95^{\circ} \mathrm{C}$. T7 polymerase was used as described in 'Materials and Methods', its activity was not affected significantly up to $10 \%$ formamide (data not shown). However, formamide concentration of higher than $10 \%$ decreased the activity of $\mathrm{T} 7$ polymerase.

\section{References}

Beyer, H. S. (1991) Blotting mRNAs with oligonucleotide probes using formamide. Biotechniques 11: 746-747

Hubbell, H. R., Sahasrabuddhe, C. G. and Hsu, T. C. (1976) Formamide denaturation of chromosomal DNA for in situ hybridization and c-band preparation in the guinea pig, Cavia porcellus. Exp. Cell. Res. 102: 385-393

Kim, Y. W., Wang, H., Sures, I., Lammers, R., Martell, K. J. and Ullrich, A. (1996) Characterization of the PEST family protein tyrosine phosphatase BDP1. Oncogene 13: 2275-2279

Mills, D. R. and Kramer, F. R. (1979) Structure-independent nucleotide sequence analysis. Proc. Natl. Acad. Sci. U.S.A. 76: 2232-2235

Mironov, V. N., Van Montagu, M. and Inze, D. (1995) High throughput RNase protection assay. Nucl. Acids Res. 23: 3359-3360

Mizusawa, S., Nishimura, S. and Seela, F. (1986) Improvement of the dideoxy chain termination method of DNA sequencing by use of deoxy-7-deazaguanosine triphosphate in place of dGTP. Nucl. Acids Res. 14: 1319-1324

Murray, M. G. (1986) Use of sodium trichloroacetate and mung bean nuclease to increase sensitivity and precision during transcript mapping. Anal. Biochem. 158: 165- 
170

Rochelear M. J., Grey R. J., Chen, D. Y., Harke, H. R. and Dovichi, N. J. (1992) Formdamide modified polycrylamide gels for DNA sequencing by capillary gel electrophoresis. Electrophoresis 13: 484-486
Sanger, F. and Coulson, A. R. (1978) The use of thin acrylamide gels for DNA sequencing. FEBS Lett. 87: 107-110 